\title{
What Do We Know about Botryosphaeriaceae? An Overview of a Worldwide Cured Dataset
}

\author{
Eduardo Batista (D), Anabela Lopes and Artur Alves*(D) \\ CESAM, Departamento de Biologia, Universidade de Aveiro, 3810-193 Aveiro, Portugal; \\ eduardobatista@ua.pt (E.B.); arlopes@ua.pt (A.L.) \\ * Correspondence: artur.alves@ua.pt
}

check for updates

Citation: Batista, E.; Lopes, A.; Alves, A. What Do We Know about Botryosphaeriaceae? An Overview of a Worldwide Cured Dataset. Forests 2021, 12, 313. https://doi.org/ $10.3390 /$ f12030313

Academic Editors: Nikica Ogrisa and Benedetto T. Linaldeddu

Received: 14 February 2021

Accepted: 3 March 2021

Published: 8 March 2021

Publisher's Note: MDPI stays neutral with regard to jurisdictional claims in published maps and institutional affiliations.

Copyright: (c) 2021 by the authors. Licensee MDPI, Basel, Switzerland. This article is an open access article distributed under the terms and conditions of the Creative Commons Attribution (CC BY) license (https:// creativecommons.org/licenses/by/ $4.0 /)$.

\begin{abstract}
Botryosphaeriaceae-related diseases occur worldwide in a wide variety of plant hosts. The number of studies targeting the distribution, diversity, ecology, and pathogenicity of Botryosphaeriaceae species are consistently increasing. However, with the lack of consistency in species delimitation, the name of hosts, and the locations of studies, it is almost impossible to quantify the presence of these species worldwide, or the number of different host-fungus interactions that occur. In this review, we collected and organized Botryosphaeriaceae occurrences in a single cured dataset, allowing us to obtain for the first time a complete perspective on species' global diversity, dispersion, host association, ecological niches, pathogenicity, communication efficiency of new occurrences, and new host-fungus associations. This dataset is freely available through an interactive and online application. The current release (version 1.0) contains 14,405 cured isolates and 2989 literature references of 12,121 different host-fungus interactions with 1692 different plant species from 149 countries.
\end{abstract}

Keywords: Botryosphaeriaceae; fungal diversity; host jumps; pathogenicity; ecological niches; quarantine measures

\section{Introduction}

Species of Botryosphaeriaceae (Botryosphaeriales, Ascomycetes) are distributed worldwide and are known to have different ecological roles. These fungi can act as saprobic, endophytic, or latent pathogens [1,2]. Some members of this family are recognized as aggressive plant pathogens on different types of hosts. From agricultural crops to ornamental and forest hosts, these fungi have no boundaries [3-8]. Their wide distribution; ability to persist endophytically; ability to become pathogenic only when their hosts are under stress, causing diseases that eventually may lead to host death; and capability to adapt and colonize new hosts $[2,9]$ makes these organisms into a great challenge for plant pathology in a changing world [10-12].

Several species of Botryosphaeriaceae currently accepted have been described in the XIX century, such as, for example, Diplodia mutila (1834), Diplodia seriata (1845), Botryosphaeria dothidea (1863), and Diplodia sapinea (1870), among others. At that time, the description of new species, as well as the taxonomic position of the family Botryosphaeriaceae, was exclusively based on their micromorphological characteristics. Therefore, over the years the taxonomic position of these organisms suffered multiple classifications (for a historical overview, see [1]).

With the use of DNA sequencing and phylogenetic methods, our understanding of the taxonomy and diversity of the Botryosphaeriaceae species has changed profoundly over time. Since 1996, several authors using sequence data have studied the phylogenetic relationships of this family, and currently 20 genera and 280 species have been described [1,13-19].

Extensive surveys reporting the diversity, distribution, and pathogenicity of Botryosphaeriaceae species have been performed in several countries, providing valuable information in terms of the frequency and diversity of hosts. These include Australia [20], Algeria [21], 
Brazil [22,23], China [24,25] Portugal [9], the United States of America [26,27], Serbia, Montenegro, Bosnia and Herzegovina [28], South Africa [7,29], and many others.

The amount of information regarding these host-fungus interactions is increasing [30]. However, due to lack of consistency in the name of fungi, the name of the host, or even the location, it is almost impossible to quantify the presence of these species worldwide or describe the number of different host-fungus interactions. Our review attempts to gather and standardize all information found in the National Center for Biotechnology Information (NCBI) nucleotide database and all the host-fungus interaction information available in the U.S. National Fungus Collections. This information was cured and organized to be easily available through a shiny interactive application.

\section{Data Analysis and Extraction}

\subsection{Data Extraction from Nucleotide-NCBI Database}

An initial query was performed on 12-05-2020 in the Nucleotide-NCBI database using the search term "Botryosphaeriaceae [Organism]" with the R package rentrez [31]. In total, 49,955 sequences were retrieved. Information such as organism, strain/culture collection, host, geographical coordinates, country, and the title of publication were also extracted (Figure 1).

Screening was performed by removing duplicates and records without a strain or culture collection number. For each isolate, when available, sequences from the internal transcribed spacer region of rRNA region (ITS), translation elongation factor 1-alpha $(t e f 1-\alpha)$, beta-tubulin (tub2), second largest subunit of RNA polymerase II (rpb2), and two alternate forms of the MAT locus (MAT1-1-1 and MAT1-2-1) were selected.

All the sequences were grouped by the strain or culture collection number and all features were manually standardized. Special characters were removed from the strain/culture collection feature and organized by the main culture collections. Geographical coordinates were transformed to the decimal form of the WGS84 geodetic datum and countries' names were organized according to the International Organization for Standardization (ISO) reference system. Host names were cured according to the Catalogue of Life: 2019 Annual Checklist from the CoL+ project [32]. Climate variables were extracted from the Climatologies at a high resolution for the Earth's land surface areas project (CHELSA) only for records with geographical coordinates [33]. The organism name was verified and updated according to recent literature and a sequence quality screening was performed by running a pairwise blast analysis between the ITS of each isolate against the sequence of the type of each genus. Isolates with a similarity lower than $94.3 \%$ were removed [34].

\subsection{Data Extraction from U.S. National Fungus Collections}

A query was performed by genus (Alanphillipsia, Barriopsis, Botryobambusa, Botryosphaeria, Cophinforma, Diplodia, Dothiorella, Endomelanconiopsis, Eutiarosporella, Lasiodiplodia, Macrophomina, Marasasiomyces, Mucoharknessia, Neodeightonia, Neofusicoccum, Neoscytalidium, Oblongocollomyces, Phaeobotryon, Sardiniella, Sphaeropsis) on 12 May 2020. Data regarding fungus-host interactions were extracted and organized by country, year, and citation. In total, 22,698 host-fungus interactions were extracted. Similarly, to the previous screening, duplicates were removed and all features were standardized by the same rules (Figure 1). 


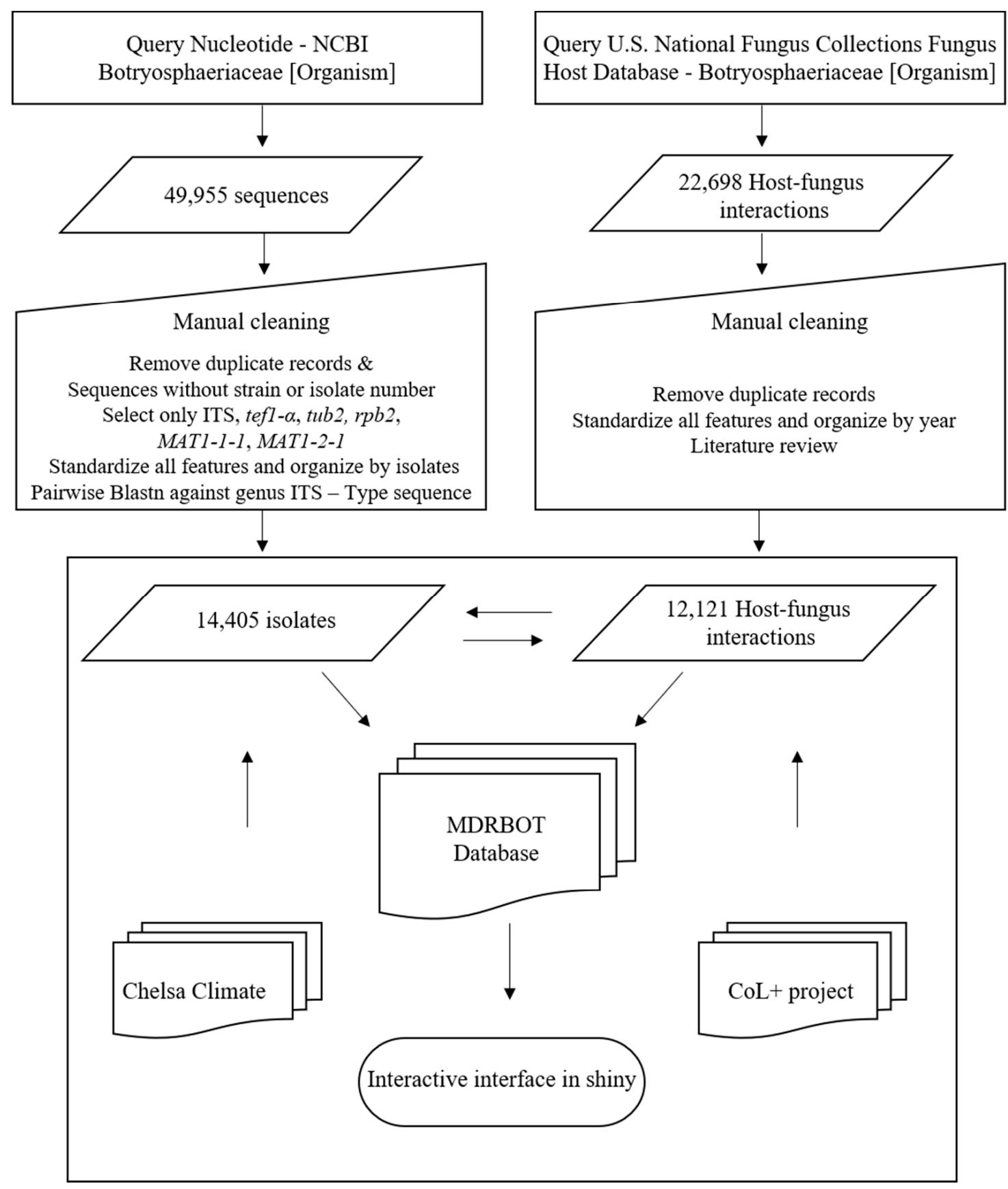

Figure 1. Workflow overview to cure and organize data extracted from the Nucleotide-NCBI database and the U.S. National Fungus Collections. Final output originated the Map Detect and Research BOTryosphaeriaceae database, which can be accessed through an interactive shiny interface.

\subsection{MDRBOT Database and Shiny Interface}

A literature review was performed, and both datasets were analyzed to fill missing information. Several extra organization-level features were built to allow different filter functions. A shiny interface was created to allow easy access to both datasets.

\subsection{The Site}

The MDRBOT database was built using R 3.6.0 with a web shiny interface. The website includes a search engine to find the cured Botryosphaeriaceae isolates from the Nucleotide-NCBI database and for the host-fungus interaction dataset, where the user can perform multiple field search and download the output in an excel format file (.xlsx). 
A worldwide map generator tool for species occurrence is available, where the user can select an input species and generate a world occurrence map. A climate data analysis is included, where the user can select an input species and observe isolates with valid geographical information and evaluate the main climate variables associated with these records (minimum, average and maximum annual temperature and minimum, average, and maximum annual precipitation). The option to download the output maps as a portable network graphics file (.png) for both occurrence and climate data analyses is also available.

\section{Diversity vs. Sampling Effort: How Much We Really Know?}

Despite all the efforts to characterize this fungal family, it is impossible to evaluate the global diversity of these organisms due to the different levels of sampling effort across countries. For this reason, we compared diversity with countries' sampling efforts using the location of isolates from the Nucleotide-GenBank collection. In this analysis, we consider that data on nucleotide are representative for the sampling effort. We found that 138 countries still have no records of Botryosphaeriaceae species deposited in GenBank (represented in white in Figure 2) and 66\% of the countries have records of less than 51 isolates. With a concentration of $80 \%$ of all isolates in only 11 countries are China (1810 isolates), United States of America (1310), South Africa (1141), Brazil (1077), Australia (796) Italy (622) Iran (439), India (412), Spain (347), Malaysia (324), and Portugal (311). In a similar way, diversity tends to increase with sampling effort, suggesting that we are still far from reaching a plateau: China (72 species), United States of America (55), South Africa (62), Brazil (42), Australia (57) Italy (51) Iran (35), India (28), Spain (31), Malaysia (17), and Portugal (23). In Figure 2, we produced a bi-variate world map to evaluate countries' diversity vs. sampling effort. The lack of data for several regions of the globe is clear, predominantly in Africa; Central and Western Europe; North, Central, and Western Asia; Bolivia; and several countries in the Caribbean region.

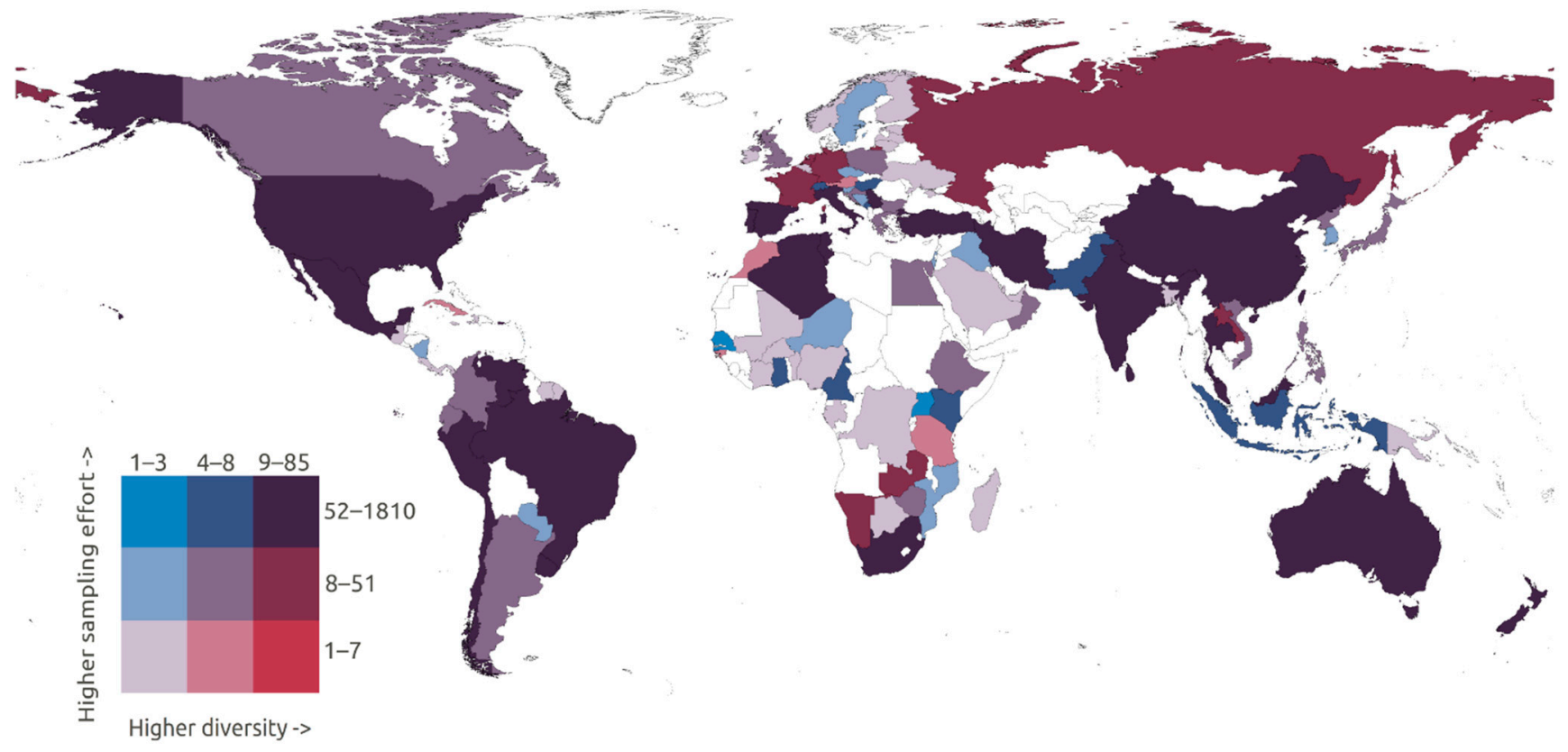

Figure 2. Bi-variate world map analyzing diversity vs. sampling effort for Botryosphaeriaceae isolates. Data obtained from Nucleotide-GenBank (a total of 14,405 isolates: 12,593 with location and 1812 isolates without location). Countries in both variables were divided in quartiles with an equal probability of occurrence (e.g., for species diversity, the probability of randomly selecting a country is equal for the intervals with $1-3,4-8$, and $9-85$ species) to facilitate visualization. 


\section{Worldwide Occurrence-From Where to Where?}

Evolutionary divergence studies show that Botryosphaeriaceae lineages emerged during the late Cretaceous period, over 66 million years ago, in a period dominated by the expansion of angiosperms occupying environments previously dominated by conifers. It is hypothesized that the evolution of modern Botryosphaeriaceae species was driven by the evolution and diversification during the Paleocene epoch of their hosts, which we currently know as modern plants $[18,35]$. Several authors have investigated the origin of some species by performing population studies at the global scale among different hosts and did not identify an obvious phylogeographic origin [6,36-41].

It is known that the infection and colonization of hosts can occur through natural wounds on leaves, branches, or stems and due to other openings such as lenticels and stomata. The distribution of these organisms is favored by the sticky spores dispersed by wind, rain, and insects [2]. At the intercontinental level, human movement, and the international trade of plants and derivates (timber and non-timber products) without appropriate quarantine measures, has caused the dispersion of these organisms [30]. Within this family, several species are known to have limited distributions, and a few species such as Botryosphaeria dothidea, Diplodia sapinea, Diplodia seriata, Dothiorella sarmentorum, Neofusicoccum parvum, and Lasiodiplodia theobromae are recognized to be globally distributed $[1,17,41]$. To understand the distribution of the main Botryosphaeriaceae species, we analyzed their spatial distributions over continents and terrestrial ecoregions [42,43]. Within the studied species, so far only Diplodia corticola and Neofusicoccum mangiferae have not been reported in every continent. This observation confirms the ability of the remaining species to spread globally. However, if we take into consideration the different terrestrial ecoregions, we can observe that some species are reported only in certain ecoregions. Based on occurrence data, we suggest a latitudinal shift among different types of climates where some species are clearly concentrated in some types of ecosystems. For example, Do. Sarmentorum, D. corticola, D. mutila, N. australe, D. seriata, and D. sapinea are found only in temperate and Mediterranean ecosystems, while others with a wider range of dispersion. Neofusicoccum parvum in our analysis appears to be the most adapted organism, with it being detected from the north to the south, with the exception of boreal forests and montane grasslands. Boreal forests appear to be the most unlikely place to find Botryosphaeriaceae species; so far, only D. sapinea has been reported in these regions (Figure 3). 

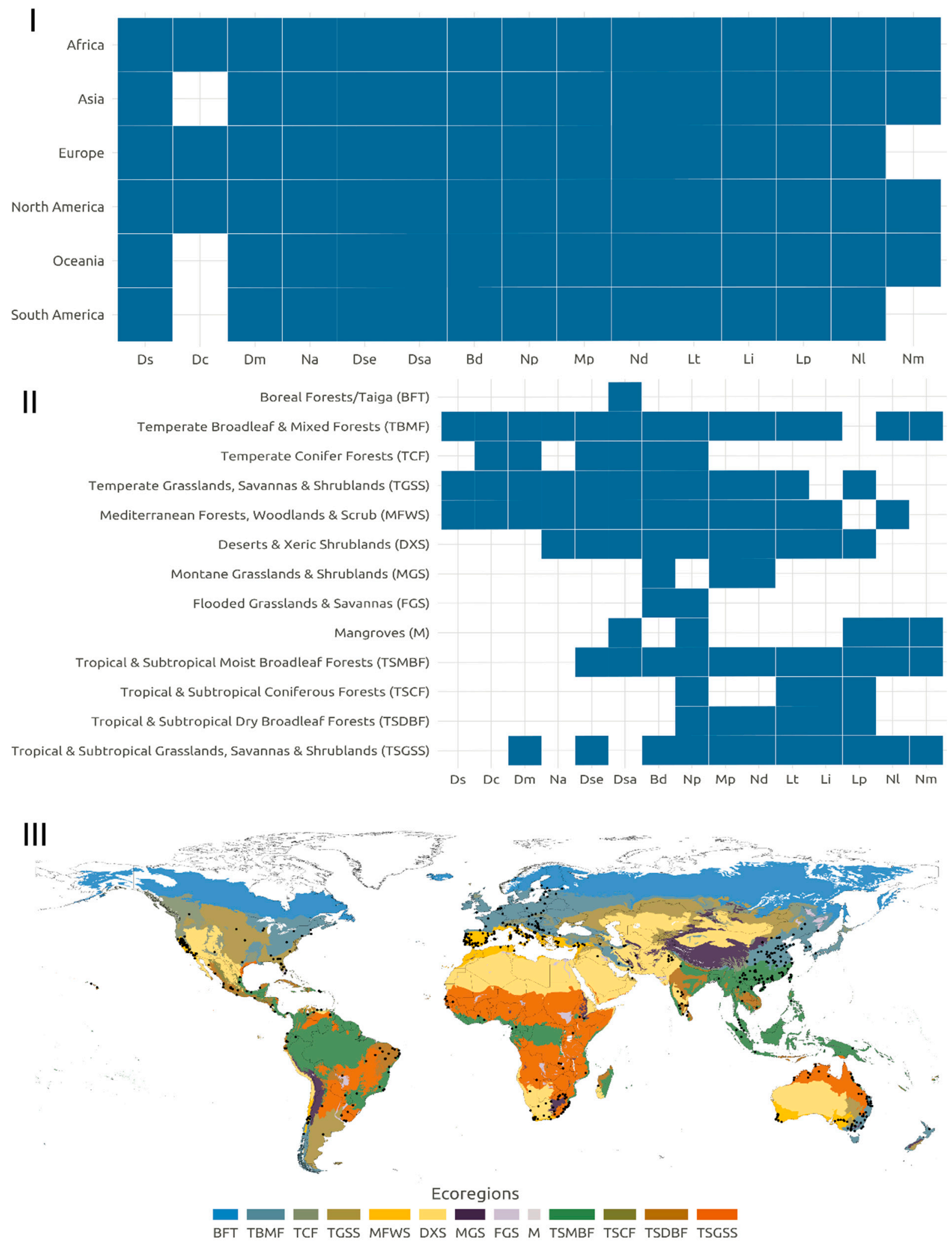

Figure 3. Worldwide occurrence of the main Botryosphaeriaceae species (B. dothidea (Bd), D. corticola (Dc), D. mutila (Dm), D. sapinea (Dsa), D. seriata (Dse), Do. sarmentorum (Ds), L. iranensis (Li), L. pseudotheobromae (Lp), L. theobromae (Lt), M. phaseolina $(\mathrm{Mp})$, N. australe $(\mathrm{Na})$, Ne. dimidiatum $(\mathrm{Nd})$, N. luteum $(\mathrm{Nl})$, N. mangiferae $(\mathrm{Nm})$, N. parvum $(\mathrm{Np}))$. Data on continental occurrence were obtained from the literature. Points represent isolates with valid geographical coordinates from the literature and GenBank. A total of 786 geographical references were used. 


\section{Understanding the Process of Host Jumps-Can We Spot Host Specificity?}

Defining a host range and understanding which factors favor future host jumps is essential to study emerging and re-emerging fungal pathogens. Several drivers are often mentioned in the literature, such as international trade, the failure of quarantine and preventive measures, changes in land use or agricultural practices, pathogen evolution and plasticity, mechanisms of genome divergence (e.g., mutation, hybridization, sexual recombination, horizontal gene transfer, and others), host-fungus genotype-by-genotype interactions, poor host health, and climate change, among others [44-49]. Comparative genomics and omics studies are slowing unveiling host-fungus interaction mechanisms by dissecting plant defence mechanisms, fungal pathogenic strategies, and nutrient uptake pathways [50-54]. To clarify a momentary host range boundary and spot host specificity, a complete overview of all the mentioned areas is crucial.

Over time, our knowledge regarding the biology and ecology of these pathogens has improved significantly. However, the mechanisms behind host jumps and the worldwide extension of host association patterns across Botryosphaeriaceae genera are still poorly understood. In general, the most studied species lack host specificity and have a proven capability to colonize and cause disease in diverse native and introduced plant hosts [2,7-9,55-58]. Even species such as D. sapinea and D. corticola, which have been consistently associated with a certain type of host, have been occasionally found to occur in other unrelated hosts in different regions of world [9,59-61].

To investigate possible host specificity, we compared the number of hosts against the total number of hosts of the genera, the number of isolates, the number of countries where these species were detected, the number of reports found in the literature, and differences between the numbers of known associations with angiosperms and gymnosperms (Figure 4). Overall, L. theobromae is by far the organism with the largest number of known hosts (666 of 749 hosts reported for the genus Lasiodiplodia), with the largest number of isolates in GenBank (1944), the largest number of country occurrences (97), and the largest number of host-fungus interaction reports (365). For the remaining species, it is possible to observe, even with different research efforts in a number of isolates or literature reports, that some species clearly have the capability to colonize a higher number of hosts than other (e.g., N. parvum with 223 hosts in 50 countries and B. dothidea with 403 hosts in 66 countries), and few have been consistently reported worldwide in a low number of hosts (e.g., D. sapinea was reported in 62 countries but only in 102 hosts, of which 83 are gymnosperms, or D. seriata with 121 hosts in 46 countries and Lasiodiplodia pseudotheobromae with 124 hosts in 44 countries).

However, a higher number of different hosts might be related only to the diversity of species among different plant functional groups and not to their ability to colonize different hosts from different plant groups. For example, the Pinopsida class-also known as conifers-has only 615 living species, while the Liliopsida (monocotyledons) and the Magnoliopsida (dicotyledons) classes have an estimated 77,267 and 246,366 living species, respectively. To analyze host jumps among different functional groups, we created a circular graph with shared hosts-fungus interactions where hosts were divided in different plants groups (Figure 5). Not surprisingly, L. theobromae showed a capability to colonize hosts in all plant groups. However, L. pseudotheobromae and N. parvum, with a considerably lower number of known hosts, present a similar pattern of shared host-fungus interactions, suggesting their clear capability to increase their host range in a similar way to that of $L$. theobromae. For other fungi, it is possible to explore range expansions: $N$. mangiferae and $L$. iraniensis have recently been described in several members of the Malvids group and are occasionally found in other groups. Diplodia sapinea has been consistently reported in the Pinales species and D. corticola in the Quercus species from the Fabids group, but both are also starting to be found in different plant groups. These types of analyses can be useful for institutions and national authorities to guide their studies and to anticipate future host jumps, especially for highly pathogenic organisms. Notably, few studies have proven 
host specialization among different Botryosphaeriaceae species based on differences in pathogenicity-related genes (e.g., B. dothidea versus Botryosphaeria kuwatsukai) [62].
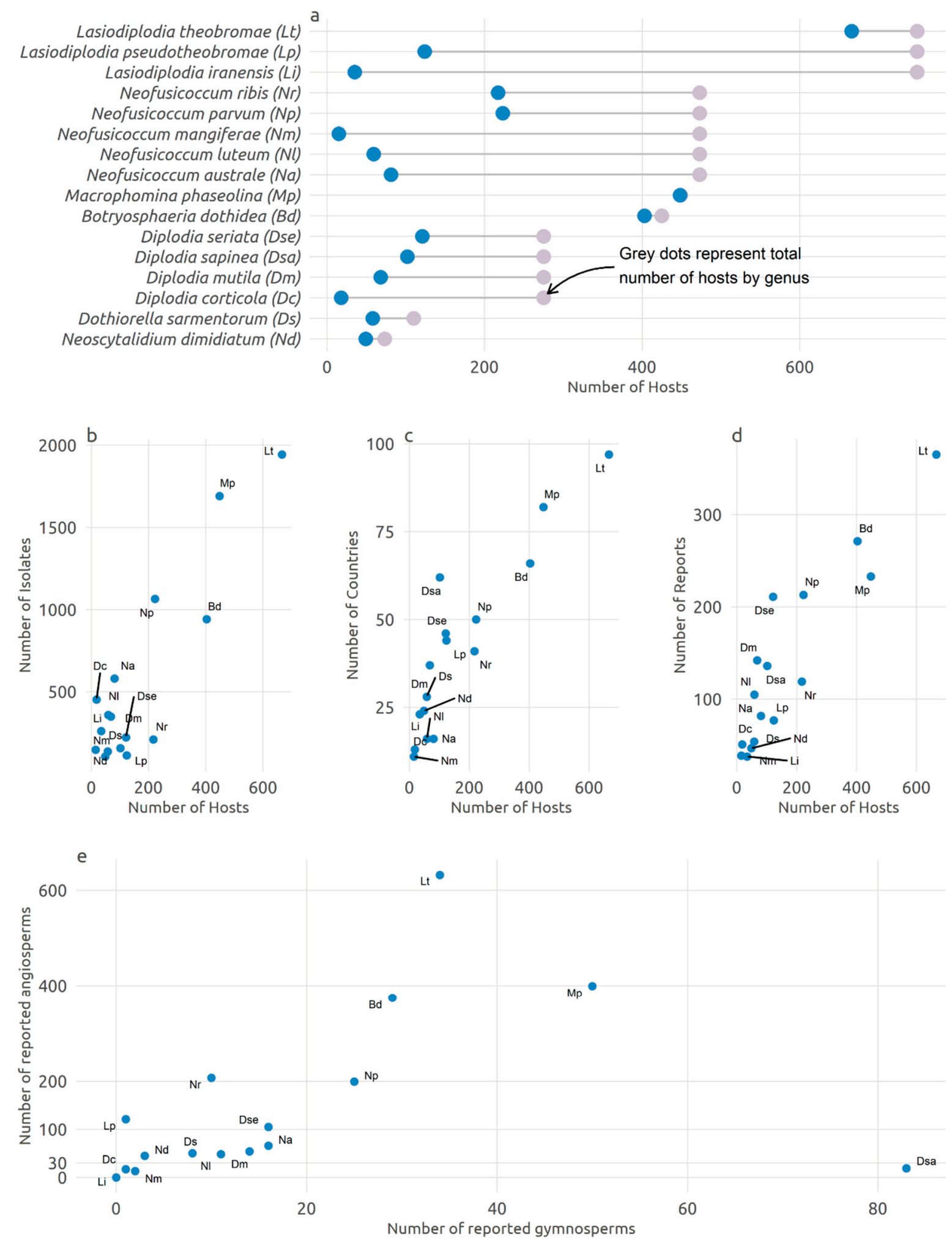

Figure 4. Host-fungus interaction overview. (a) Comparison of the number of hosts by species within genera, (b) number of isolates versus number of hosts, (c) number of countries vs. number of hosts, (d) number of reports vs. number of hosts, and (e) number of known host associations with angiosperms vs. gymnosperms. Data were collected from GenBank and a literature review. Only host-fungus interactions identified at the species level were selected. 

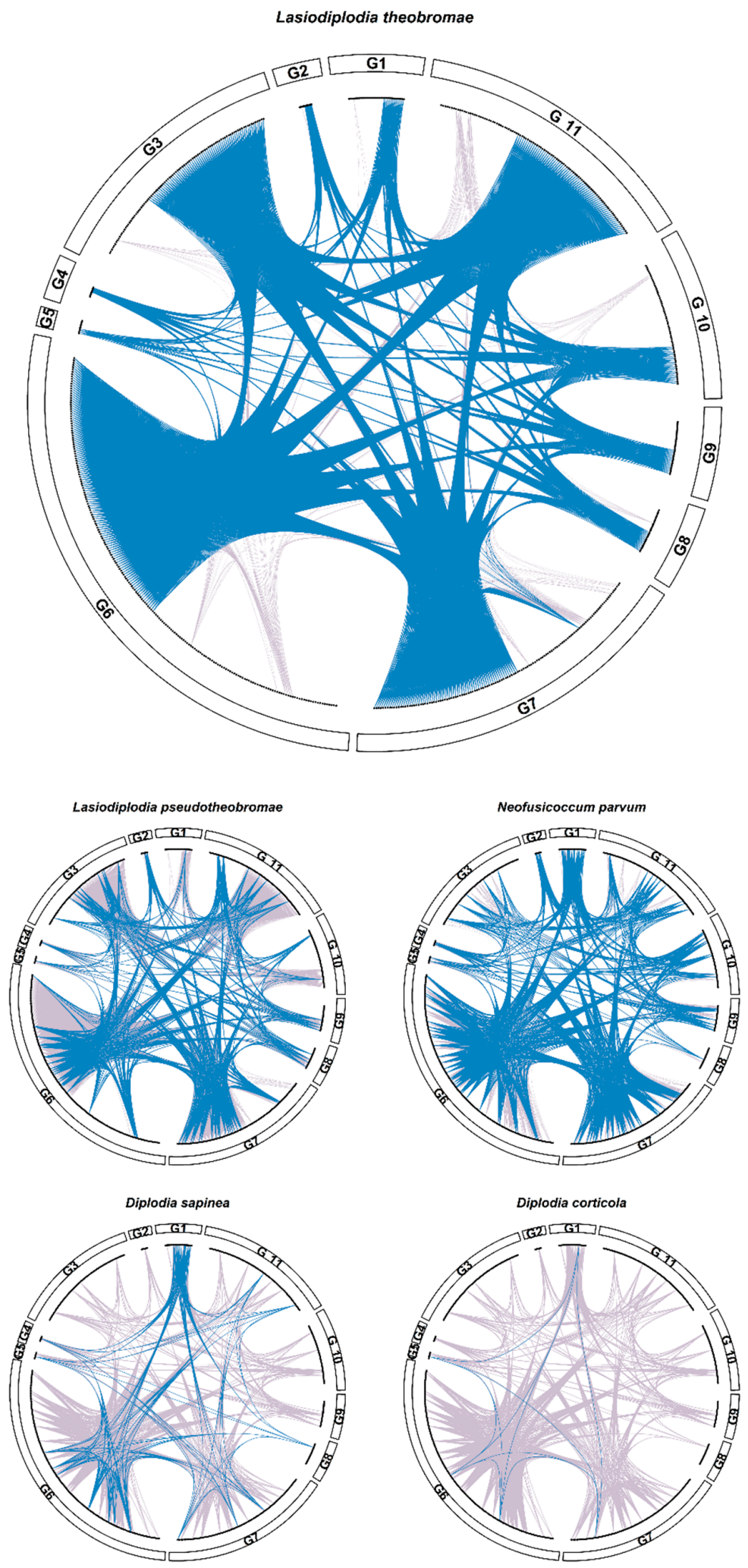

Figure 5. Shared host interactions worldwide based on GenBank and a literature review. Nodes represent hosts genera and are grouped by taxonomic similarity. G1: Pinales and Ginkgoales; G2: Magnoliids; G3: Monocots; G4: Eudicots; G5: Superrosids and Rosids; G6: Fabids; G7: Malvids; G8: Superasterids; G9: Asterids; G10: Campanulids; G11: Lamiids. Lines represent host-fungus interactions, where background lines represent all known interactions of the respective Botryosphaeriaceae genus and blue lines represent known interactions of the respective Botryosphaeriaceae species. 


\section{How Much We Know about Pathogenicity and Plant Mortality?}

Uncovering the complexity of host-pathogen interaction is not a stationary science and depends on multiple variables from the environment and the interaction of both hosts' and pathogens' genome artillery [63,64]. Host-pathogen interactions are similar to a chess game, where for a specific outcome several actions are possible from each organism. The reproducibility of these interactions under controlled conditions might not always be representative of what occurs in nature, and common pathogenicity trials do not fully expose pathogenic and resistance mechanisms $[65,66]$. Nonetheless, the sequence and annotation of both genomes opens the possibility for multi-omics analyses to provide a more complete overview of these interactions $[53,67]$.

The pathogenicity of Botryosphaeriaceae isolates leading to plant mortality has been demonstrated under controlled conditions, mainly in seedlings, in well-watered conditions or under drought stress $[9,68,69]$. However, plant mortality in nature is often a combination of multiple biotic and abiotic stresses. On one hand, abiotic factors such as drought or heat stress can disrupt plant physiological performance, allowing the colonization of fungal pathogens and increasing disease susceptibility. On the other hand, colonization by fungal pathogens can reduce tolerance to biotic stress, leading to higher mortality rates [63,70-72]. The interaction effects of drought and fungal pathogen infection on plant mortality are shown in Figure 6.

Several factors can induce mortality, such as carbon starvation when non-structural carbohydrates resources are depleted, affecting normal plant maintenance, growth, and defence mechanisms [73]; the toxic effect of fungal metabolites; and the hydraulic failure of xylem water transport to the leaves due to embolism or phloem transport caused by an impaired xylem water potential [74]. These factors can be directly or indirectly induced by both biotic and abiotic stresses. For example, drought and heat stress can induce stomata closure and simultaneously decrease carbon assimilation, which is essential in maintaining plant defence metabolism and functional sapwood maintenance. Pathogen infection can directly impact carbon assimilation by down-regulating the genes involved in photosynthetic activities or triggering carbon starvation by inducing tree defences and/or inhibiting the expression of genes involved in carbon metabolism and transport. Additionally, when these pathogens colonize plant vascular tissues and vascular necrosis occurs, the whole-plant hydraulic conductance is reduced, increasing the risk of hydraulic failure [74].

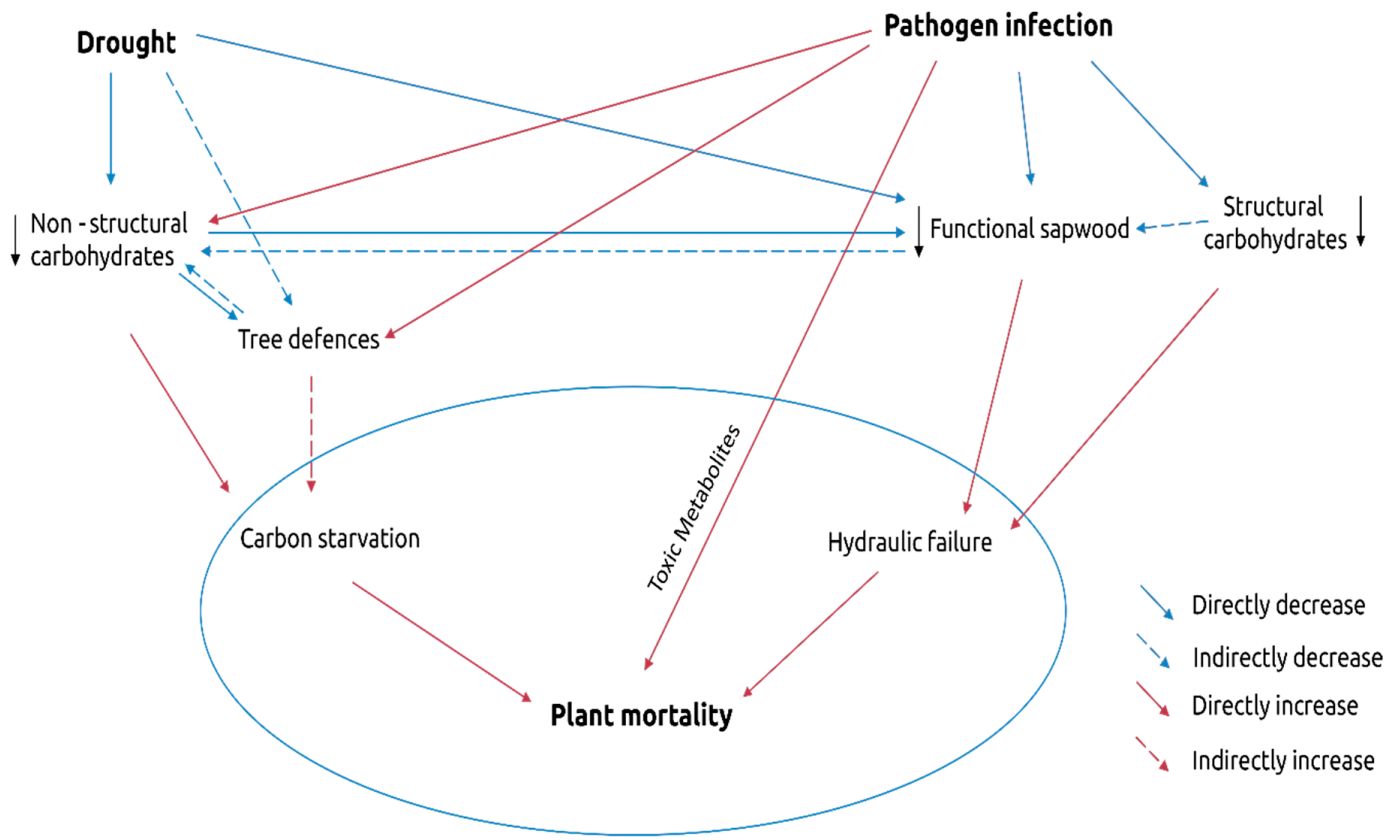

Figure 6. Combined effects of drought and pathogen infection on plant functioning, growth, and mortality. Adapted from $[72,74]$. 
Genome and transcriptome analyses of some Botryosphaeriaceae species have shown a higher number of pathogenicity-related genes associated with cell wall degradation, nutrient uptake, secondary metabolism, and membrane transport functions, which are important for woody plant infection when compared with other fungi with different lifestyles [62,75]. Additionally, several authors have demonstrated that, during infection, gene families related to carbohydrate catabolism; pectin, starch, and sucrose metabolism; pentose and glucuronate interconversion pathways were induced [76-78]. Some of these genes' families were even induced by higher temperatures [54,75].

Furthermore, some species were proven to have the capability to exhibit cytotoxicity against mammalian cell lines, and again temperature was suggested to modulate the expression of toxic compounds [54,79,80].

\section{Climate Sensitivity, a Hidden Pattern?}

Temperature growth studies suggest that, in general, Botryosphaeriaceae species present minimal growth rates at $5{ }^{\circ} \mathrm{C}$ or over $35^{\circ} \mathrm{C}$ and optimal growth rates at around $15-25^{\circ} \mathrm{C}$ under controlled conditions $[1,17]$. So far, no major studies have been performed to characterize the natural bioclimatic envelopes of Botryosphaeriaceae species. Based on the geographical coordinates obtained during this review, we analyzed the climatic variability of these records (Figure 7). In terms of annual mean temperature, it is clear that B. dothidea, D. seriata, and Do. iberica are often collected in places with lower annual mean temperatures when compared with L. theobromae, M. phaseolina, N. paroum, and Ne. dimidiatum. For annual precipitation, this pattern is not so clear, with the exception of L. theobromae, where the majority of records were collected in places with more than $1000 \mathrm{~mm}$ of annual precipitation (typical of tropical regions). Temperature and precipitation seasonality were calculated using the standard deviation of the mean monthly values. Regions with larger standard deviations have greater temperature and precipitation variability across the year. These metrics are important in understanding the tolerance range for species in the future. For example, a species that is often present in tropical regions with a tolerance to higher annual mean temperatures but without tolerance to strong temperature seasonality may have problems expanding its distribution range in the future to a region with a strong temperature variability across the year, even if the mean temperature increases (e.g., can L. theobromae, often collected in tropical regions, expand its range to Mediterranean and temperate regions with climate change?)

These results are consistent with our ecoregions analysis, suggesting that probably the known host-fungus interactions and species distributions are strongly dependent on climate. We encourage authors to provide precise coordinates for occurrence data to improve the understanding of the Botryosphaeriaceae species distribution.

\section{Global Dispersion-How Far Can They Go? \\ Framing Ecological Niche Requirements for Potential Species Distributions Areas}

As mentioned before, the Botryosphaeriaceae species produce spores that are naturally dispersed through wind, rain, insects. However, human-induced activities are responsible for the majority of long-distance dispersion [2,30]. Taking into account the large number of potential hosts and the large quantity of plant material moving worldwide every day, it is virtually impossible to verify and detect efficiently latent pathogens living endophytically in symptomatic or asymptomatic material [30,81,82]. Thus, understanding the ecological niche requirements for potential species distribution areas might be a better solution to predict and prevent future outbreaks [83].

We propose an adaptation of the classical BAM diagram (Figure 8I) to explain the influence of environmental conditions, biotic interactions, and dispersal in shaping species' geographic distribution [85-87]. Following the classical BAM diagram, $B$ represents the geographic regions where the interaction factors with other species are favorable for species occurrence, $A$ represents the geographical regions where the climatic conditions are favorable for maintaining a viable long-term population, and $M$ corresponds to the geographical 
region accessible for species dispersion. However, for endophytes and latent pathogens, this perspective does not fully represent the ecological dynamics of these organisms. We assume that: (1) endophytic latent pathogens are mainly dispersed by human activities such as movement and trade; (2) the introduction of a species in a new environment is likely to occur, as human movement/trade exists and is favored by a lack of preventive and quarantine measures, therefore $M$ is virtually unlimited; (3) the establishment of these species is affected by climate. Nonetheless, unfavorable conditions might hide the presence of those species in asymptomatic hosts or by resistance structures. Seasonal effects might expand or decrease the growth of these organisms, invalidating viable long-term populations. (4) Optimal conditions for disease expression are mainly occasional climatic events that can affect the susceptibility of the host (i.e., a reduction in precipitation or/and temperature increments could cause drought or heat stress to the host $[70,88,89])$ or/and trigger the pathogenic behavior of these organisms (i.e., variations in temperature, light intensity, or atmospheric ozone could induce phytopathogenic mechanisms $[54,79,80,90,91])$, (5) Only when host specificity is demonstrated, whether for a fungal species with a limited ability to colonize and persist endophytically in certain hosts or/and for species with limited ability to infect and express disease symptoms in a certain type of hosts, is it assumed that biotic interactions (B) can shape the geographical distribution (Figure 8II).
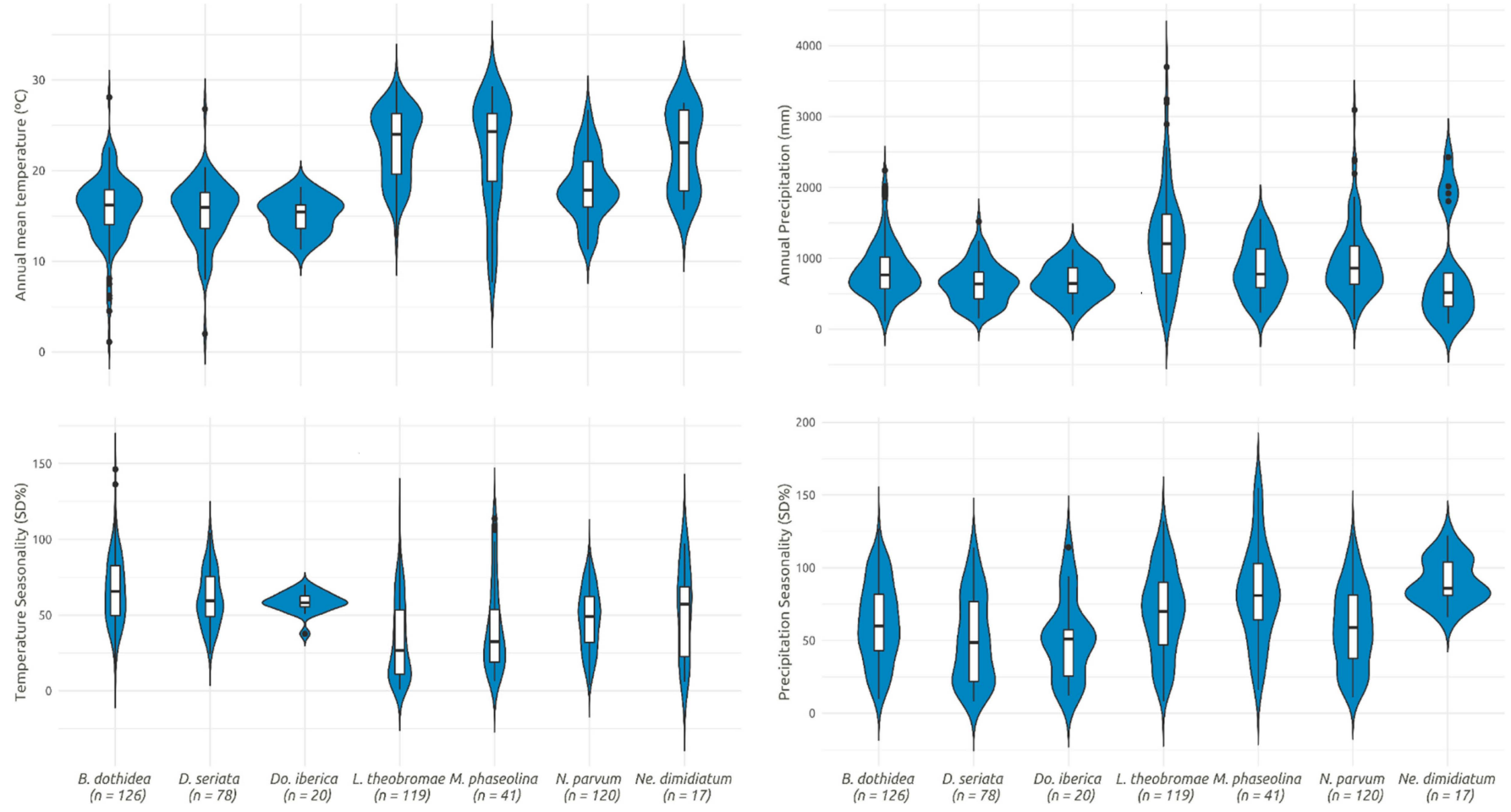

Figure 7. Annual mean temperature and precipitation and temperature and precipitation seasonality for the main Botryosphaeriaceae species occurrence. Data were thinned by $200 \mathrm{~km}$ distance to avoid spatial autocorrelation using the R package ELSA (Entropy-Based Local Indicator of Spatial Association) [84]. Climatic variables were extracted from the CHELSA project. Number of valid coordinates are indicated per species.

As a result, for non-specific endophytes and latent pathogens, like many of the Botryosphaeriaceae species, assuming an imperfect quarantine system worldwide, climate is the main variable constraining the geographical distribution of these organisms. 


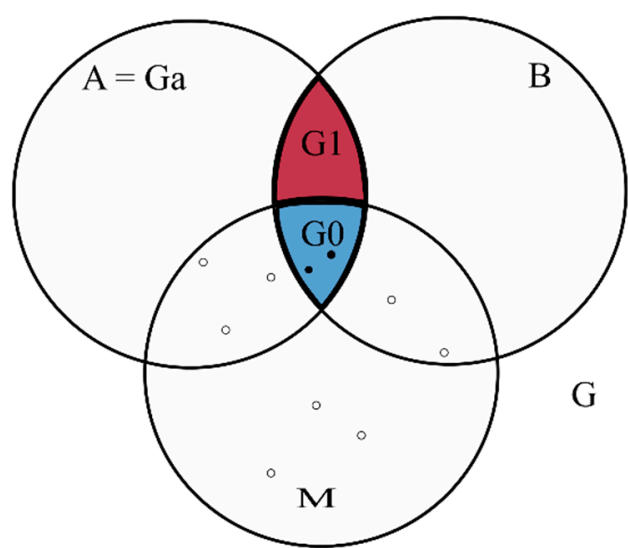

II

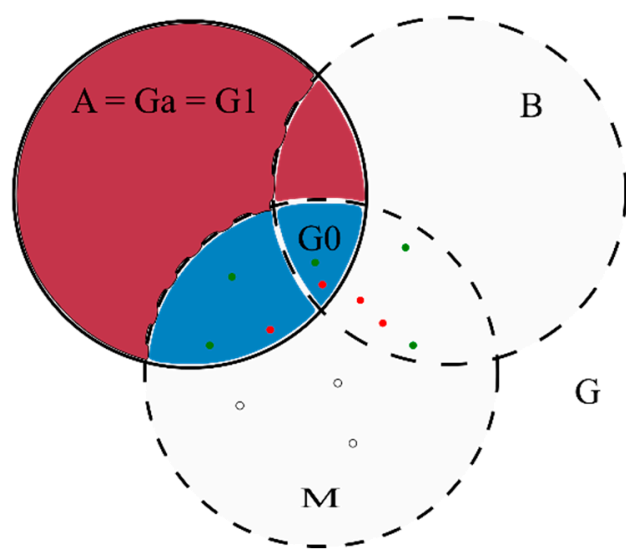

Figure 8. (I) Representation of the classical BAM diagram adapted from Peterson (2012). (II) Variation of the BAM diagram to represent endophytes and latent pathogens such as Botryosphaeriaceae species. Three factors are suggested to define species geographic distribution: biotic (B), abiotic (A), and movement (M). By interactions among these factors four areas, we can define: $G$, the geographic space within which analyses are developed; Ga, the abiotically suitable area; G0, the occupied distributional area; G1, the invadable distributional area. Black solid circles indicate species occurrence, red solid circles indicate occurrence in symptomatic hosts, green solid circles indicate occurrence in asymptomatic hosts, and open circles indicate absences.

\section{How Good Are We at Reporting New Occurrences and Host-Fungus Associations?}

Despite the increase in new Botryosphaeriaceae-related studies worldwide, there is still a lack of standard databases that are consistently curated and maintained over time. The failure in efficiently reporting new occurrences and host-fungus associations increases the gap between science and society and dilutes the scientific effort to improve preventive and quarantine policy measures. Information regarding this fungal family is often reported in indexed scientific journals and should be followed by public sequence data that allow the scientific community to validate and confirm the taxonomic identification of these organisms. If information only present in the literature might be outdated and difficult to verify, information only presented in GenBank or similar databases is also susceptible to be lost without a proper report. Ideally, a report of a new occurrence or a new host-fungus interaction should be documented in the literature and supported with public genomic data. These data should be well-organized in public databases to allow national institutions such as customs or agricultural/forestry authorities to be prepared for possible new threats.

In Figure 9, we compare the country occurrences and host-fungus interactions by country that are reported only in the literature, in both the literature and GenBank, and only reported in GenBank. We also classified countries by the percentage of information that is not properly reported. We found that only $53.69 \%$ of the species occurrence by country is reported in both datasets, and if we take in consideration host-fungus interactions by 
country, only $23.07 \%$ of the current knowledge is well reported. Records prior to the massification of DNA-based methodologies (older than the year 2000) are often poorly reported, but there is also a large number of recent studies that fail to provide consistent information about host and location even when public genomic data are available.
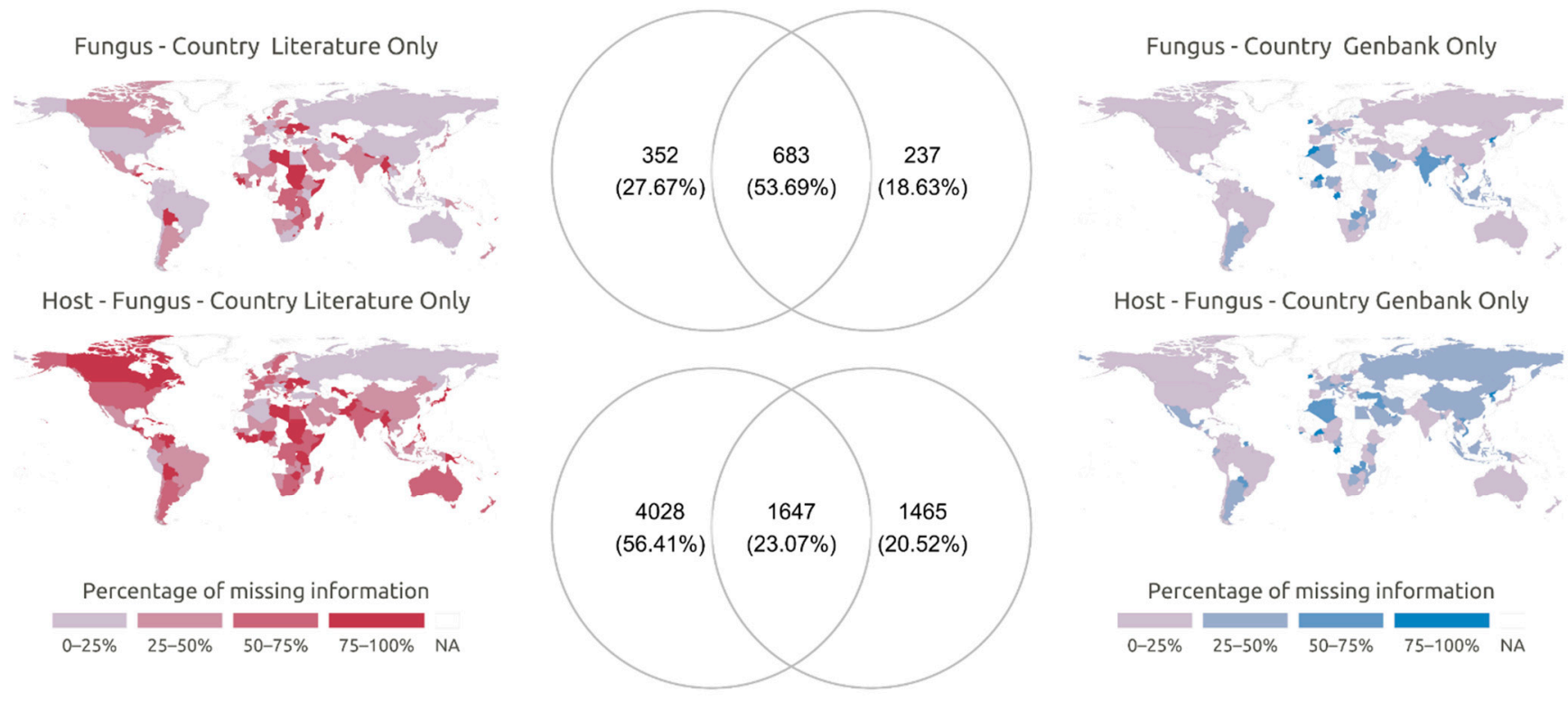

Figure 9. Worldwide percentage of missing information in both the literature and GenBank datasets by country for occurrence and host-fungus interactions.

\section{Conclusions and Future Perspectives}

Our database represents a single effort to clean and organize all Botryosphaeriaceaerelated occurrences. This database will be continuously maintained and researchers working with these organisms are welcome to submit or update their information. Major updates on the source information are expected to happen every January and new features may be added over time as a result of users' feedback.

With the insights of a worldwide cured dataset, we verify a consistent growing interest of these plant pathogenic fungi when taking in account the number of public records and publications and the citation history of papers over the years [30]. However, we demonstrate that $80 \%$ of all isolates with public sequence data are concentrated only in 11 countries, leading to a huge knowledge gap regarding Botryosphaeriaceae's occurrence and diversity worldwide. Additionally, even countries with a higher sampling effort are still far from reaching a plateau for species diversity versus sampling effort, suggesting a high number of undescribed species. The problematic of estimating species numbers is a common issue in other fungal families [92], raising the concern of fully understanding the limit of a species boundary and properly identifying cryptic species on species interactions, as well the recognition of the hybridization phenomenon $[36,93,94]$.

In terms of ecology, we reflect about the climate influence on the distribution and dispersion of these organisms for the first time. Despite the worldwide distribution across all continents, with the exception of Antarctica, it was possible to observe a climatic preference for some species (e.g., D. corticola, Do. sarmentorum, or N. australe) in temperate and Mediterranean regions and other species with a wider tolerance in temperate to tropical regions (e.g., B. dothidea, N. paroum, or M. phaseolina). In terms of dispersion, we propose a new framework to define the ecological niche requirements for most fungal latent endophytes. This framework is essential to improve our understanding of the current species distributions areas and to forecast future disease outbreaks [83]. We assume that human movement and trade are the main dispersion routes of these organisms, with climate variability being the major constrain for the occurrence of new stable populations. 
Additionally, we highlight that disease expression is mainly due to occasional climatic events that can affect the susceptibility of the host. Raising the importance to sample asymptomatic hosts for an early detection of new species occurrence (e.g., Diplodia insularis was reported for the first time in Portugal in an asymptomatic host [9]).

To finalize, we evaluate the consistency of known species occurrence and host associations reports in both indexed scientific journals and public sequence databases. We demonstrate the incapability of our society to efficiently use and aggregate data of these emergent plant-pathogens. More than never, we consider that consistent and open plant pathology databases are fundamental to address the challenge of Botryosphaeriaceaerelated diseases in a changing world.

Author Contributions: E.B. and A.A. planned and designed the research. E.B. and A.L. collected and analyzed data. E.B., A.L. and A.A. wrote the manuscript. All authors have read and agreed to the published version of the manuscript.

Funding: Thanks are due to the Portuguese Foundation for Science and Technology (FCT/MCTES) for the financial support to CESAM (UIDP/50017/2020 + UIDB/50017/2020), and the PhD grant of Eduardo Batista (PD/BD/135535/2018).

Data Availability Statement: The data can be found here: https://mdr-bot-cesam-ua.shinyapps.io/ bot_database (accessed on 7 March 2021); https://github.com/Batis007/MDRBOT (accessed on 7 March 2021).

Acknowledgments: We thank Lisa Castlebury for supplying the data from the U.S. National Fungus Collections.

Conflicts of Interest: The authors declare no conflict of interest.

\section{References}

1. Phillips, A.J.L.; Alves, A.; Abdollahzadeh, J.; Slippers, B.; Wingfield, M.J.; Groenewald, J.Z.; Crous, P.W. The Botryosphaeriaceae: Genera and species known from culture. Stud. Mycol. 2013, 76, 51-167. [CrossRef]

2. Slippers, B.; Wingfield, M.J. Botryosphaeriaceae as endophytes and latent pathogens of woody plants: Diversity, ecology and impact. Fungal Biol. Rev. 2007, 21, 90-106. [CrossRef]

3. Trakunyingcharoen, T.; Cheewangkoon, R.; To-Anun, C.; Crous, P.W.; Van Niekerk, J.M.; Lombard, L. Botryosphaeriaceae associated with diseases of mango (Mangifera Indica). Australas. Plant Pathol. 2014, 43, 425-438. [CrossRef]

4. Linaldeddu, B.T.; Deidda, A.; Scanu, B.; Franceschini, A.; Serra, S.; Berraf-Tebbal, A.; Zouaoui Boutiti, M.; Ben Jamâa, M.L.; Phillips, A.J.L. Diversity of Botryosphaeriaceae species associated with grapevine and other woody hosts in Italy, Algeria and Tunisia, with descriptions of Lasiodiplodia exigua and Lasiodiplodia mediterranea sp. nov. Fungal Divers. 2015, 71, 201-214. [CrossRef]

5. Moricca, S.; Linaldeddu, B.T.; Ginetti, B.; Scanu, B.; Franceschini, A.; Ragazzi, A. Endemic and emerging pathogens threatening cork oak trees: Management options for conserving a unique forest ecosystem. Plant Dis. 2016, 100, 2184-2193. [CrossRef]

6. Marsberg, A.; Kemler, M.; Jami, F.; Nagel, J.H.; Postma-Smidt, A.; Naidoo, S.; Wingfield, M.J.; Crous, P.W.; Spatafora, J.W.; Hesse, C.N.; et al. Botryosphaeria dothidea: A latent pathogen of global importance to woody plant health. Mol. Plant Pathol. 2017, 18, 477-488. [CrossRef] [PubMed]

7. Mehl, J.W.M.; Slippers, B.; Roux, J.; Wingfield, M.J. Overlap of latent pathogens in the Botryosphaeriaceae on a native and agricultural host. Fungal Biol. 2017, 121, 405-419. [CrossRef]

8. Zlatković, M.; Wingfield, M.J.; Jami, F.; Slippers, B. Host specificity of co-infecting Botryosphaeriaceae on ornamental and forest trees in the Western Balkans. For. Pathol. 2018, 48, e12410. [CrossRef]

9. Batista, E.; Lopes, A.; Alves, A. Botryosphaeriaceae species on forest trees in Portugal: Diversity, distribution and pathogenicity. Eur. J. Plant Pathol. 2020, 158, 693-720. [CrossRef]

10. Anderson, P.K.; Cunningham, A.A.; Patel, N.G.; Morales, F.J.; Epstein, P.R.; Daszak, P. Emerging infectious diseases of plants: Pathogen pollution, climate change and agrotechnology drivers. Trends Ecol. Evol. 2004, 19, 535-544. [CrossRef]

11. Elad, Y.; Pertot, I. Climate change impacts on plant pathogens and plant diseases. J. Crop Improv. 2014, 28, 99-139. [CrossRef]

12. La Porta, N.; Capretti, P.; Thomsen, I.M.; Kasanen, R.; Hietala, A.M.; Von Weissenberg, K. Forest pathogens with higher damage potential due to climate change in Europe. Can. J. Plant. Pathol. 2008, 30, 177-195. [CrossRef]

13. Schoch, C.L.; Shoemaker, R.A.; Seifert, K.A.; Hambleton, S.; Spatafora, J.W.; Crous, P.W. A multigene phylogeny of the Dothideomycetes using four nuclear loci. Mycologia 2006, 98, 1041-1052. [CrossRef] [PubMed]

14. Crous, P.W.; Slippers, B.; Wingfield, M.J.; Rheeder, J.; Marasas, W.F.O.; Philips, A.J.L.; Alves, A.; Burgess, T.; Barber, P.; Groenewald, J.Z. Phylogenetic lineages in the Botryosphaeriaceae. Stud. Mycol. 2006, 55, 235-253. [CrossRef] 
15. Phillips, A.J.L.; Alves, A.; Pennycook, S.R.; Johnston, P.R.; Ramaley, A.; Akulov, A.; Crous, P.W. Resolving the phylogenetic and taxonomic status of dark-spored teleomorph genera in the Botryosphaeriaceae. Persoonia Mol. Phylogeny Evol. Fungi 2008, $21,29-55$. [CrossRef] [PubMed]

16. Liu, J.K.; Phookamsak, R.; Doilom, M.; Wikee, S.; Li, Y.M.; Ariyawansha, H.; Boonmee, S.; Chomnunti, P.; Dai, D.Q.; Bhat, J.D.; et al. Towards a natural classification of Botryosphaeriales. Fungal Divers. 2012, 57, 149-210. [CrossRef]

17. Dissanayake, A.J.; Phillips, A.J.L.; Li, X.H.; Hyde, K.D. Botryosphaeriaceae: Current status of genera and species. Mycosphere 2016, 7, 1001-1073. [CrossRef]

18. Phillips, A.J.L.L.; Hyde, K.D.; Alves, A.; Liu, J.-K.J. Families in Botryosphaeriales: A phylogenetic, morphological and evolutionary perspective. Fungal Divers. 2019, 94, 1-22. [CrossRef]

19. Slippers, B.; Roux, J.; Wingfield, M.J.; van der Walt, F.J.J.; Jami, F.; Mehl, J.W.M.; Marais, G.J. Confronting the constraints of morphological taxonomy in the Botryosphaeriales. Persoonia Mol. Phylogeny Evol. Fungi 2014, 33, 155-168. [CrossRef] [PubMed]

20. Burgess, T.I.; Tan, Y.P.; Garnas, J.; Edwards, J.; Scarlett, K.A.; Shuttleworth, L.A.; Daniel, R.; Dann, E.K.; Parkinson, L.E.; Dinh, Q.; et al. Current status of the Botryosphaeriaceae in Australia. Australas. Plant. Pathol. 2018, 48, 35-44. [CrossRef]

21. Mahamedi, A.E.; Phillips, A.J.L.; Lopes, A.; Djellid, Y.; Arkam, M.; Eichmeier, A.; Zitouni, A.; Alves, A.; Berraf-Tebbal, A. Diversity, distribution and host association of Botryosphaeriaceae species causing oak decline across different forest ecosystems in Algeria. Eur. J. Plant. Pathol. 2020, 158, 745-765. [CrossRef]

22. Netto, M.S.B.; Assunção, I.P.; Lima, G.S.A.; Marques, M.W.; Lima, W.G.; Monteiro, J.H.A.; de Queiroz Balbino, V.; Michereff, S.J.; Phillips, A.J.L.; Câmara, M.P.S. Species of Lasiodiplodia associated with papaya stem-end rot in Brazil. Fungal Divers. 2014, 67, 127-141. [CrossRef]

23. Rosado, A.W.C.; Machado, A.R.; das Chagas Oliveira Freire, F.; Pereira, O.L. Phylogeny, Identification, and Pathogenicity of Lasiodiplodia Associated with Postharvest Stem-End Rot of Coconut in Brazil. Plant. Dis. 2016, 100, 561-568. [CrossRef]

24. Li, G.Q.; Liu, F.F.; Li, J.Q.; Liu, Q.L.; Chen, S.F. Botryosphaeriaceae from Eucalyptus plantations and adjacent plants in China. Persoonia Mol. Phylogeny Evol. Fungi 2018, 40, 63-95. [CrossRef] [PubMed]

25. Xu, C.; Zhang, H.; Zhou, Z.; Hu, T.; Wang, S.; Wang, Y.; Cao, K. Identification and distribution of Botryosphaeriaceae species associated with blueberry stem blight in China. Eur. J. Plant. Pathol. 2015, 143, 737-752. [CrossRef]

26. Inderbitzin, P.; Bostock, R.M.; Trouillas, F.P.; Michailides, T.J. A six locus phylogeny reveals high species diversity in Botryosphaeriaceae from California almond. Mycologia 2010, 102, 1350-1368. [CrossRef] [PubMed]

27. Chen, S.F.; Morgan, D.P.; Michailides, T.J. Botryosphaeriaceae and Diaporthaceae associated with panicle and shoot blight of pistachio in California, USA. Fungal Divers. 2014, 67, 157-179. [CrossRef]

28. Zlatković, M.; Keča, N.; Wingfield, M.J.; Jami, F.; Slippers, B. Botryosphaeriaceae associated with the die-back of ornamental trees in the Western Balkans. Antonie Van Leeuwenhoek 2016, 109, 543-564. [CrossRef]

29. Osorio, J.A.; Crous, C.J.; de Beer, Z.W.; Wingfield, M.J.; Roux, J. Endophytic Botryosphaeriaceae, including five new species, associated with mangrove trees in South Africa. Fungal Biol. 2017, 121, 361-393. [CrossRef]

30. Slippers, B.; Crous, P.W.; Jami, F.; Groenewald, J.Z.; Wingfield, M.J. Diversity in the Botryosphaeriales: Looking back, looking forward. Fungal Biol. 2017, 121, 307-321. [CrossRef]

31. Winter, D.J. rentrez: An R package for the NCBI eUtils API. PeerJ Preprints 2017, 5, e3179v2. [CrossRef]

32. Bisby, F.A.; Roskov, Y.; Orrell, T.M.; Nicolson, D.; Paglinawan, L.E.; Bailly, N.; Kirk, P.M.; Bourgoin, T.; Baillargeon, G.; Ouvrard, D. Species 2000 \& ITIS Catalogue of Life. 2010. Available online: http:/ / centaur.reading.ac.uk/18493/ (accessed on 12 May 2020).

33. Karger, D.N.; Conrad, O.; Böhner, J.; Kawohl, T.; Kreft, H.; Soria-Auza, R.W.; Zimmermann, N.E.; Linder, H.P.; Kessler, M. Climatologies at high resolution for the earth's land surface areas. Sci. Data 2017, 4, 170122. [CrossRef]

34. Vu, D.; Groenewald, M.; de Vries, M.; Gehrmann, T.; Stielow, B.; Eberhardt, U.; Al-Hatmi, A.; Groenewald, J.Z.; Cardinali, G.; Houbraken, J.; et al. Large-scale generation and analysis of filamentous fungal DNA barcodes boosts coverage for kingdom fungi and reveals thresholds for fungal species and higher taxon delimitation. Stud. Mycol. 2019, 92, 135-154. [CrossRef]

35. Slippers, B.; Boissin, E.; Phillips, A.J.L.; Groenewald, J.Z.; Lombard, L.; Wingfield, M.J.; Postma, A.; Burgess, T.; Crous, P.W. Phylogenetic lineages in the Botryosphaeriales: A systematic and evolutionary framework. Stud. Mycol. 2013, 76, 31-49. [CrossRef] [PubMed]

36. Sakalidis, M.L.; Slippers, B.; Wingfield, B.D.; Hardy, G.E.S.J.; Burgess, T.I. The challenge of understanding the origin, pathways and extent of fungal invasions: Global populations of the Neofusicoccum parvum-N. ribis species complex. Divers. Distrib. 2013, 19, 873-883. [CrossRef]

37. Burgess, T.I.; Wingfield, M.J. Quarantine is important in restricting the spread of exotic seed-borne tree pathogens in the southern hemisphere. Int. For. Rev. 2002, 4, 56-65.

38. Burgess, T.I.; Wingfield, M.J.; Wingfield, B.D. Global distribution of Diplodia pinea genotypes revealed using simple sequence repeat (SSR) markers. Australas. Plant. Pathol. 2004, 33, 513-519. [CrossRef]

39. Bihon, W.; Burgess, T.; Slippers, B.; Wingfield, M.J.; Wingfield, B.D. High levels of genetic diversity and cryptic recombination is widespread in introduced Diplodia pinea populations. Australas. Plant. Pathol. 2012, 41, 41-46. [CrossRef]

40. Salahlou, R.; Safaie, N.; Shams-Bakhsh, M. Genetic diversity of Macrophomina phaseolina populations, the causal agent of sesame charcoal rot using inter-simple sequence repeat markers. J. Agric. Sci. Technol. 2016, 18, $277-287$.

41. Mehl, J.; Wingfield, M.J.; Roux, J.; Slippers, B. Invasive everywhere? Phylogeographic analysis of the globally distributed tree pathogen Lasiodiplodia theobromae. Forests 2017, 8, 145. [CrossRef] 
42. Dinerstein, E.; Olson, D.; Joshi, A.; Vynne, C.; Burgess, N.D.; Wikramanayake, E.; Hahn, N.; Palminteri, S.; Hedao, P.; Noss, R.; et al. An Ecoregion-Based Approach to Protecting Half the Terrestrial Realm. Bioscience 2017, 67, 534-545. [CrossRef] [PubMed]

43. Olson, D.M.; Dinerstein, E.; Wikramanayake, E.D.; Burgess, N.D.; Powell, G.V.N.; Underwood, E.C.; D'Amico, J.A.; Itoua, I.; Strand, H.E.; Morrison, J.C.; et al. Terrestrial ecoregions of the world: A new map of life on Earth. Bioscience 2001, 51, 933-938. [CrossRef]

44. Lambrechts, L. Dissecting the genetic architecture of host-pathogen specificity. PLoS Pathog. 2010, 6, e1001019. [CrossRef] [PubMed]

45. Gange, A.C.; Gange, E.G.; Mohammad, A.B.; Boddy, L. Host shifts in fungi caused by climate change? Fungal Ecol. 2011, 4, 184-190. [CrossRef]

46. De Fine Licht, H.H. Does pathogen plasticity facilitate host shifts? PLoS Pathog. 2018, 14, e1006961. [CrossRef]

47. Brown, J.K.M.; Tellier, A. Plant-parasite coevolution: Bridging the gap between genetics and ecology. Annu. Rev. Phytopathol. 2011, 49, 345-367. [CrossRef]

48. Burdon, J.J.; Silk, J. Sources and patterns of diversity in plant-pathogenic fungi. Phytopathology 1997, 87, 664-669. [CrossRef]

49. Corredor-Moreno, P.; Saunders, D.G.O. Expecting the unexpected: Factors influencing the emergence of fungal and oomycete plant pathogens. New Phytol. 2020, 225, 118-125. [CrossRef]

50. Möller, M.; Stukenbrock, E.H. Evolution and genome architecture in fungal plant pathogens. Nat. Rev. Microbiol. 2017, 15, 756-771. [CrossRef]

51. Raffaele, S.; Kamoun, S. Genome evolution in filamentous plant pathogens: Why bigger can be better. Nat. Rev. Microbiol. 2012, 10, 417-430. [CrossRef]

52. Han, G.Z. Origin and evolution of the plant immune system. New Phytol. 2019, 222, 70-83. [CrossRef]

53. Westermann, A.J.; Barquist, L.; Vogel, J. Resolving host-pathogen interactions by dual RNA-seq. PLoS Pathog. 2017, 13, e1006033. [CrossRef] [PubMed]

54. Félix, C.; Meneses, R.; Gonçalves, M.F.M.; Tilleman, L.; Duarte, A.S.; Jorrín-Novo, J.V.; Van de Peer, Y.; Deforce, D.; Van Nieuwerburgh, F.; Esteves, A.C.; et al. A multi-omics analysis of the grapevine pathogen Lasiodiplodia theobromae reveals that temperature affects the expression of virulence- and pathogenicity-related genes. Sci. Rep. 2019, 9, 1-12. [CrossRef] [PubMed]

55. De Wet, J.; Slippers, B.; Preisig, O.; Wingfield, B.D.; Wingfield, M.J. Phylogeny of the Botryosphaeriaceae reveals patterns of host association. Mol. Phylogenet. Evol. 2008, 46, 116-126. [CrossRef]

56. Jami, F.; Wingfield, M.J.; Gryzenhout, M.; Slippers, B. Diversity of tree-infecting Botryosphaeriales on native and non-native trees in South Africa and Namibia. Australas. Plant. Pathol. 2017, 46, 529-545. [CrossRef]

57. Pavlic-Zupanc, D.; Maleme, H.M.; Piškur, B.; Wingfield, B.D.; Wingfield, M.J.; Slippers, B. Diversity, phylogeny and pathogenicity of Botryosphaeriaceae on non-native Eucalyptus grown in an urban environment: A case study. Urban. For. Urban. Green. 2017, 26, 139-148. [CrossRef]

58. Liddle, R.L.; Akinsanmi, O.A.; Galea, V.J. Non-host specificity of Botryosphaeriaceae on macadamia and blueberry. Australas. Plant. Pathol. 2019, 48, 65-73. [CrossRef]

59. Lazzizera, C.; Frisullo, S.; Alves, A.; Lopes, J.; Phillips, A.J.L. Phylogeny and morphology of Diplodia species on olives in southern Italy and description of Diplodia olivarum sp nov. Fungal Divers. 2008, 31, 63-71.

60. Barradas, C.; Phillips, A.J.L.; Correia, A.; Diogo, E.; Bragança, H.; Alves, A. Diversity and potential impact of Botryosphaeriaceae species associated with Eucalyptus globulus plantations in Portugal. Eur. J. Plant. Pathol. 2016, 146, 245-257. [CrossRef]

61. Zlatković, M.; Keča, N.; Wingfield, M.J.; Jami, F.; Slippers, B. New and unexpected host associations for Diplodia sapinea in the Western Balkans. For. Pathol. 2017, 47, e12328. [CrossRef]

62. Wang, B.; Liang, X.; Gleason, M.L.; Zhang, R.; Sun, G. Comparative genomics of Botryosphaeria dothidea and B. kuwatsukai, causal agents of apple ring rot, reveals both species expansion of pathogenicity-related genes and variations in virulence gene content during speciation. IMA Fungus 2018, 9, 243-257. [CrossRef]

63. Hossain, M.; Veneklaas, E.J.; Hardy, G.E.S.J.; Poot, P. Tree host-pathogen interactions as influenced by drought timing: Linking physiological performance, biochemical defence and disease severity. Tree Physiol. 2018, 39, 6-18. [CrossRef]

64. Gururani, M.A.; Venkatesh, J.; Upadhyaya, C.P.; Nookaraju, A.; Pandey, S.K.; Park, S.W. Plant disease resistance genes: Current status and future directions. Physiol. Mol. Plant. Pathol. 2012, 78, 51-65. [CrossRef]

65. Félix, C.; Pinto, G.; Amaral, J.; Fernandes, I.; Alves, A.; Esteves, A.C. Strain-related pathogenicity in Diplodia corticola. For. Pathol. 2017, 47, e12366. [CrossRef]

66. Manawasinghe, I.; Phillips, A.; Hyde, K.; Chethana, K.; Zhang, W.; Zhao, W.; Yan, J.; Li, X. Mycosphere Essays 14: Assessing the aggressiveness of plant pathogenic Botryosphaeriaceae. Mycosphere 2016, 7, 883-892. [CrossRef]

67. Westermann, A.J.; Förstner, K.U.; Amman, F.; Barquist, L.; Chao, Y.; Schulte, L.N.; Müller, L.; Reinhardt, R.; Stadler, P.F.; Vogel, J. Dual RNA-seq unveils noncoding RNA functions in host-pathogen interactions. Nature 2016, 529, 496-501. [CrossRef]

68. Pitt, W.M.; Huang, R.; Steel, C.C.; Savocchia, S. Pathogenicity and epidemiology of Botryosphaeriaceae species isolated from grapevines in Australia. Australas. Plant. Pathol. 2013, 42, 573-582. [CrossRef]

69. Linaldeddu, B.T.; Franceschini, A.; Luque, J.; Phillips, A.J.L. First Report of Canker Disease Caused by Botryosphaeria parva on Cork Oak Trees in Italy. Plant. Dis. 2007, 91, 324. [CrossRef] 
70. Allen, C.D.; Macalady, A.K.; Chenchouni, H.; Bachelet, D.; McDowell, N.; Vennetier, M.; Kitzberger, T.; Rigling, A.; Breshears, D.D.; Hogg, E.H.T.; et al. A global overview of drought and heat-induced tree mortality reveals emerging climate change risks for forests. For. Ecol. Manag. 2010, 259, 660-684. [CrossRef]

71. Wang, W.; Peng, C.; Kneeshaw, D.D.; Larocque, G.R.; Luo, Z. Drought-induced tree mortality: Ecological consequences, causes, and modeling. Environ. Rev. 2012, 20, 109-121. [CrossRef]

72. Caldeira, M.C. The timing of drought coupled with pathogens may boost tree mortality. Tree Physiol. 2019, 39, 1-5. [CrossRef] [PubMed]

73. Li, P.; Liu, W.; Zhang, Y.; Xing, J.; Li, J.; Feng, J.; Su, X.; Zhao, J. Fungal canker pathogens trigger carbon starvation by inhibiting carbon metabolism in poplar stems. Sci. Rep. 2019, 9, 1-14. [CrossRef]

74. Oliva, J.; Stenlid, J.; Martínez-Vilalta, J. The effect of fungal pathogens on the water and carbon economy of trees: Implications for drought-induced mortality. New Phytol. 2014, 203, 1028-1035. [CrossRef]

75. Yan, J.Y.; Zhao, W.S.; Chen, Z.; Xing, Q.K.; Zhang, W.; Chethana, K.W.T.; Xue, M.F.; Xu, J.P.; Phillips, A.J.L.; Wang, Y.; et al. Comparative genome and transcriptome analyses reveal adaptations to opportunistic infections in woody plant degrading pathogens of Botryosphaeriaceae. DNA Res. 2018, 25, 87-102. [CrossRef]

76. Gonçalves, M.F.M.; Nunes, R.B.; Tilleman, L.; Van De Peer, Y.; Deforce, D.; Van Nieuwerburgh, F.; Esteves, A.C.; Alves, A. Dual RNA sequencing of Vitis vinifera during Lasiodiplodia theobromae infection unveils host-pathogen interactions. Int. J. Mol. Sci. 2019, 20, 6083. [CrossRef]

77. Ali, S.S.; Asman, A.; Shao, J.; Balidion, J.F.; Strem, M.D.; Puig, A.S.; Meinhardt, L.W.; Bailey, B.A. Genome and transcriptome analysis of the latent pathogen Lasiodiplodia theobromae, an emerging threat to the cacao industry. Genome 2020, 63, 37-52. [CrossRef]

78. Massonnet, M.; Morales-Cruz, A.; Figueroa-Balderas, R.; Lawrence, D.P.; Baumgartner, K.; Cantu, D. Condition-dependent co-regulation of genomic clusters of virulence factors in the grapevine trunk pathogen Neofusicoccum parvum. Mol. Plant. Pathol. 2018, 19, 21-34. [CrossRef] [PubMed]

79. Félix, C.; Duarte, A.S.; Vitorino, R.; Guerreiro, A.C.L.; Domingues, P.; Correia, A.C.M.; Alves, A.; Esteves, A.C. Temperature modulates the secretome of the phytopathogenic fungus Lasiodiplodia theobromae. Front. Plant. Sci. 2016, 7, 1-12. [CrossRef]

80. Nazar Pour, F.; Ferreira, V.; Félix, C.; Serôdio, J.; Alves, A.; Duarte, A.S.; Esteves, A.C. Effect of temperature on the phytotoxicity and cytotoxicity of Botryosphaeriaceae fungi. Fungal Biol. 2020, 124, 571-578. [CrossRef]

81. Crous, P.W.; Groenewald, J.Z.; Slippers, B.; Wingfield, M.J. Global food and fibre security threatened by current inefficiencies in fungal identification. Philos. Trans. R. Soc. B Biol. Sci. 2016, 371, 20160024. [CrossRef] [PubMed]

82. Burgess, T.I.; Crous, C.J.; Slippers, B.; Hantula, J.; Wingfield, M.J. Tree invasions and biosecurity: Eco-evolutionary dynamics of hitchhiking fungi. AoB Plants 2016, 8. [CrossRef] [PubMed]

83. Bosso, L.; Luchi, N.; Maresi, G.; Cristinzio, G.; Smeraldo, S.; Russo, D. Predicting current and future disease outbreaks of Diplodia sapinea shoot blight in Italy: Species distribution models as a tool for forest management planning. For. Ecol. Manag. 2017, 400, 655-664. [CrossRef]

84. Naimi, B.; Hamm, N.A.S.; Groen, T.A.; Skidmore, A.K.; Toxopeus, A.G.; Alibakhshi, S. ELSA: Entropy-based local indicator of spatial association. Spat. Stat. 2019, 29, 66-88. [CrossRef]

85. Soberon, J.; Peterson, A.T. Interpretation of Models of Fundamental Ecological Niches and Species' Distributional Areas. Biodivers. Inform. 2005, 2, 10. [CrossRef]

86. Peterson, A.T.; Soberón, J.; Pearson, R.G.; Anderson, R.P.; Martínez-Meyer, E.; Nakamura, M.; Araújo, M.B. Ecological Niches and Geographic Distributions; Princeton University Press: Princeton, NJ, USA, 2011.

87. Pulliam, H.R. On the relationship between niche and distribution. Ecol. Lett. 2000, 3, 349-361. [CrossRef]

88. Barradas, C.; Pinto, G.; Correia, B.; Castro, B.B.; Phillips, A.J.L.; Alves, A. Drought $\times$ disease interaction in Eucalyptus globulus under Neofusicoccum eucalyptorum infection. Plant. Pathol. 2018, 67, 87-96. [CrossRef]

89. Ragazzi, A.; Moricca, S.; Dellavalle, I. Water stress and the development of cankers by Diplodia mutila on Quercus robur. J. Phytopathol. 1999, 147, 425-428. [CrossRef]

90. Eastburn, D.M.; McElrone, A.J.; Bilgin, D.D. Influence of atmospheric and climatic change on plant-pathogen interactions. Plant. Pathol. 2011, 60, 54-69. [CrossRef]

91. Herrera-Estrella, A.; Horwitz, B.A. Looking through the eyes of fungi: Molecular genetics of photoreception. Mol. Microbiol. 2007, 64, 5-15. [CrossRef]

92. Hyde, K.D.; Jeewon, R.; Chen, Y.J.; Bhunjun, C.S.; Calabon, M.S.; Jiang, H.B.; Lin, C.G.; Norphanphoun, C.; Sysouphanthong, P.; Pem, D.; et al. The Numbers of Fungi: Is the Descriptive Curve Flattening? Fungal Divers. 2020, 103, 219-271. [CrossRef]

93. Cruywagen, E.M.; Slippers, B.; Roux, J.; Wingfield, M.J. Phylogenetic species recognition and hybridisation in Lasiodiplodia: A case study on species from baobabs. Fungal Biol. 2017, 121, 420-436. [CrossRef] [PubMed]

94. Rodríguez-Gálvez, E.; Guerrero, P.; Barradas, C.; Crous, P.W.; Alves, A. Phylogeny and pathogenicity of Lasiodiplodia species associated with dieback of mango in Peru. Fungal Biol. 2017, 121, 452-465. [CrossRef] [PubMed] 